\title{
Is Netrin-1 Associated with the Development of Fibrosis in Systemic
}

\section{Sclerosis?}

Yüksel Maraş ${ }^{1}$, Ahmet Kor ${ }^{2}$, Esra Firat Oğuz ${ }^{3}$, Alper Sar1 ${ }^{4}$, Kevser Gök ${ }^{5}$, Ali Akdoğan ${ }^{6}$

${ }^{1}$ Department of Rheumatology, Health Sciences University Ankara City Hospital

${ }^{2}$ Department of Rheumatology, Ankara Y1ldırım Beyazit University Faculty of Medicine Ankara

City Hopital, Ankara, TURKEY

${ }^{3}$ Department of Medical Biochemistry, University of Health Sciences Ankara City Hospital, Ankara, Turkey

${ }^{4}$ Deparment of Rheumatology, Ankara Y1ldirim Beyazit University, Yenimahalle Training and Research Hospital, Ankara, Turkey.

${ }^{5}$ Department of Rheumatology, Health Sciences University Ankara City Hospital

${ }^{6}$ Department of Rheumatology, Hacettepe University Medical Faculty, Ankara, Turkey.

Corresponding author: DR. Ahmet Kor, Department of Rheumatology, Ankara Yıldırım Beyazıt University Faculty of Medicine Ankara City, Universities District 1604. Street No: 9 Çankaya/ANKARA/TURKEY Email: ahmetkor_61@hotmail.com Phone: +90-5326468661

Author contributions: $\mathrm{YM}, \mathrm{AK}, \mathrm{EFO}$, and $\mathrm{KG}$ collected laboratory data; $\mathrm{YM}, \mathrm{AK}, \mathrm{KG}, \mathrm{AS}$ and AA collected and analyzed clinical data; YM, AK designed the study; Data analysis and interpretation: all authors; AK wrote the article; Article draft and revision: YM, AK, AA

Supporting Sources: This study was supported by the Turkish Rheumatology Association. 
medRxiv preprint doi: https://doi.org/10.1101/2022.02.05.22270510; this version posted February 10, 2022. The copyright holder for this preprint (which was not certified by peer review) is the author/funder, who has granted medRxiv a license to display the preprint in It is made available under a CC-BY-NC-ND 4.0 International license .

\section{KEY MESSAGES}

\section{What is already known about this subject?}

Netrin-1 has proangiogenic, antiapoptotic,c, and anti-inflammatory properties and is closely related to the development of fibrosis.

\section{What does this study add?}

There are no studies evaluating Netrin-1 plasma levels in the SSc patient population. This is the first study to show that Netrin-1 plasma levels are significantly higher in SSc than in healthy people $(\mathrm{p}<0.001)$.

\section{How might this impact clinical practice or future developments?}

Considering the known roles of VEGF and M2 macrophages in the development of SSc and their close relationship with Netrin-1, further studies in this area seem to create a fertile field in understanding the complex pathophysiology of SSc and offering new therapeutic options.

Keywords: Netrin-1, systemic sclerosis, fibrosis 
medRxiv preprint doi: https://doi.org/10.1101/2022.02.05.22270510; this version posted February 10, 2022. The copyright holder for this preprint (which was not certified by peer review) is the author/funder, who has granted medRxiv a license to display the preprint in

It is made available under a CC-BY-NC-ND 4.0 International license .

\begin{abstract}
Objectives and Aims: Netrin-1 is a laminin class protein that guides the axonal during the first embryonic development, has pushing and pulling properties and axonal chemoattractant activity. Netrin-1 has been shown to increase the development of fibrosis in mouse lung and human SSc lung cell culture. In this study, we aimed to investigate the relationship between Netrin-1 and Systemic sclerosis (SSc) and to emphasize the role of Netrin-1 in the pathophysiology of SSc, by increasing the known VEGF and M2 macrophage expression, which supports the fibrotic process.
\end{abstract}

Methods: The study included $56 \mathrm{SSc}$ patients with a mean age of $48.08 \pm 13.59$ years and 58 healthy volunteers with a mean age of $48.01 \pm 11.59$ years. SSc organ involvements were scanned retrospectively from patient files and patients were grouped according to SSc complications. Calculation of Netrin-1 levels was performed using a quantitative sandwich enzyme immunoassay method with an ELISA kit (Elabscience, Texas, USA; catalog number: EEL-H2328; lot number: GZWTKZ5SWK). Modified Rodnan scoring (MRS) was used for skin thickness scoring in SSc patients.

Results: The mean of Netrin-1 was found to be significantly higher in SSc (309.51 \pm 211.86$)$ than in controls $(125.36 \pm 83.8)(\mathrm{p}<0.001)$. In ROC analysis, a cut-off value of 354.24 for Netrin in SSc was found to provide a diagnostic sensitive confidence interval with $32.8 \%$ sensitivity and $98.3 \%$ specificity (AUC[95\% CI]: 0.746-0.895, $\mathrm{p}<0.001$ ). There was no significant correlation between netrin-1 level, organ involvement in SSc, and MRS ( $p>0.05)$.

Conclusion: In this study, we found that there is a significant relationship between Netrin-1 levels and SSc disease. Our study is the first clinical study in which Netrin-1 elevation was demonstrated in SSc patients. 
medRxiv preprint doi: https://doi.org/10.1101/2022.02.05.22270510; this version posted February 10, 2022. The copyright holder for this preprint (which was not certified by peer review) is the author/funder, who has granted medRxiv a license to display the preprint in

It is made available under a CC-BY-NC-ND 4.0 International license .

\section{INTRODUCTION}

Systemic sclerosis ( $\mathrm{SSc}$ ), often called scleroderma, is an autoimmune, destructive systemic connective tissue disease characterized by organ fibrosis and vasculopathy. Pathophysiological mechanisms that may play a role in disease development include platelet activation, fibroblast proliferation, endothelial disruption, fetal microchimerism, and increased transforming growth factor- $\beta$. In addition, VEGF is an important signaling factor contributing to the pathogenesis of SSc, even in the earliest clinically detectable stages of the disease.[1]

Netrin-1 is a laminin class protein that provides axonal guidance during the first embryonic development and has axonal chemoattractant activity by binding to UNC5 (uncoordinated-5) and DCC (Deleted in Colorectal Cancer) receptors.[2] In an animal study conducted by Aranzazu M. and et al. it was determined that when 8-week-old arthritis mice were treated with anti-Netrin- 1 or anti-Unc $5 b$ antibodies for 4 weeks, there was a significant decrease in inflammation $(\mathrm{p}<0.001)$ and joint erosion, did not develop when compared to mice that did not receive treatment. This study also showed a reduction in cathepsin $\mathrm{K}+$ and $\mathrm{CD} 68+$ cells and a marked reduction in osteoclasts in animals treated with anti-Netrin-1/anti-Unc $5 \mathrm{~b}$. It has been shown that blockade of Netrin-1/Unc5b with anti-Netrin-1/anti-Unc5b antibodies prevents bone loss and reduces the severity of arthritis provoked by $\mathrm{K} / \mathrm{BxN}$ serum transfer.[3] Similarly, another animal study showed that Netrin-1 is an autocrine and paracrine factor that increases osteoclast differentiation and function by being produced by osteoclast precursors and inflammatory cells.[4] Studies in the field of obesity have shown that the exit of macrophages from the inflammatory environment is prevented by Netrin-1, and thus Netrin-1 contributes to the development of atherosclerosis.[5-7] Unlike these results, there are also studies showing that Netrin-1 has proangiogenic,[8] antiapoptotic,[9] and anti-inflammatory properties,[10] as well as cardioprotective effects against myocardial damage[11] and reducing endothelial dysfunction in diabetes[12]. It is thought that Netrin-1 has proangiogenic properties by increasing VEGF expression and VEGF receptor response.[13-15] 
medRxiv preprint doi: https://doi.org/10.1101/2022.02.05.22270510; this version posted February 10, 2022. The copyright holder for this preprint (which was not certified by peer review) is the author/funder, who has granted medRxiv a license to display the preprint in

It is made available under a CC-BY-NC-ND 4.0 International license .

The relationship between SSc, which is characterized by skin and organ fibrosis, and Netrin-1 is not fully known. In a limited number of studies conducted in this area, it has been shown that Netrin-1 increases the development of fibrosis in bleomycin-induced mouse lung and SSc lung cell culture. $[16,17]$ However, there is no study evaluating plasma Netrin-1 levels in SSc and complications related to SSc. In this study, we aimed to evaluate the levels of Netrin1 between SSc and healthy controls and to emphasize the role of the known effects of Netrin-1 in the pathophysiology of SSc, which increases VEGF and supports the fibrotic process.

\section{MATERIAL AND METHOD}

\section{Patients}

A total of 56 SSc patients (mean age: $48.08 \pm 13.59$ ) consisting of 53 females and 3 males, who were followed up in the rheumatology department of Ankara city hospital, diagnosed according to the 2013 ACR (American College of Rheumatology)/EULAR (European League Against Rheumatism) SSc classification criteria were included in the study. For the control group, 58 healthy volunteers (mean age: $48.01 \pm 11.59$ years) consisting of 54 females and 4 males were included in the study. Organ involvement due to SSc was scanned retrospectively from patient files and patients were grouped according to complications. Modified Rodnan scoring (MRS) was used for skin thickness scoring in SSc patients. For MRS, 17 body areas were evaluated and scored in the range of 0-51 points.

\section{Obtaining Sample Samples and Calculating Netrin-1 Values}

Venous blood samples were centrifuged at $1300 \mathrm{x}$ g for 10 minutes in vacuum tubes of approximately $10 \mathrm{~mL}$. Samples divided into Eppendorf tubes were kept at $-80{ }^{\circ} \mathrm{C}$ until analysis. Calculation of Netrin-1 levels was performed using a quantitative sandwich enzyme immunoassay method with an ELISA kit (Elabscience, Texas, USA; catalog number: E-ELH2328; lot number: GZWTKZ5SWK).

Netrin-1 standards and serum samples added to micro ELISA plate wells and combined with their specific antibodies were incubated for 1.5 hours at $37^{\circ} \mathrm{C}$, followed by Netrin-1 
medRxiv preprint doi: https://doi.org/10.1101/2022.02.05.22270510; this version posted February 10, 2022. The copyright holder for this preprint (which was not certified by peer review) is the author/funder, who has granted medRxiv a license to display the preprint in

It is made available under a CC-BY-NC-ND 4.0 International license .

specific biotin-enriched detection antibody and incubated for an additional 1 hour at $37^{\circ}$.

A biotin-enriched detection antibody specific for Avidin-Horseradish Peroxidase (HRP) and human Netrin- 1 was then added and incubated at $37^{\circ} \mathrm{C}$ for 30 minutes. After washing the free components, substrate solution was added to each well. After this treatment, only wells containing biotin-enriched detection antibodies, human Netrin-1, and Avidin-HRP conjugate were detected in blu. The yellow color was obtained by the termination of the enzyme-substrate reaction after the addition of the stop solution. A microplate reader at $450 \mathrm{~nm}$ wavelength was used for optical density measurement by spectrophotometric measurement. Optical density level increases in direct proportion to the concentration of human Netrin-1. The human Netrin-1 level in the study samples was calculated based on a comparison of the optical density standard curves of the samples. The test was sensitive to detect the Netrin-1 level range of 31.25-2000 $\mathrm{pg} / \mathrm{mL}$. Inter-assay and intra-assay precision of $<\% 10$ was available for all low, medium, and high Netrin-1 concentrations.

\section{Statistical analysis}

Kolmogorov Smirnov test was used to determine the normal distribution in continuous variables. Mann Whitney UU test and Independent Samples T-Test was used to determine the statistically significant difference between the groups. Pearson correlation analysis was used to determine the correlation between study parameters. Parametric and nonparametric statistical results of the variables were expressed as mean \pm standard deviation and median (minimummaximum), respectively. The statistical analyzes were calculated using the 'Statistical Packages for the Social sciences(SPSS) version 21.0 package program, and the $\mathrm{p}<0.05$ level was taken as the lower limit that was considered statistically significant. While testing the diagnostic accuracy measures of the indexes, ROC analysis was used and AUC was presented with $95 \%$ confidence intervals. Youden's index was used while determining the optimum cut-off value and diagnostic accuracy criteria for the cut-off value were presented. 
medRxiv preprint doi: https://doi.org/10.1101/2022.02.05.22270510; this version posted February 10, 2022. The copyright holder for this preprint (which was not certified by peer review) is the author/funder, who has granted medRxiv a license to display the preprint in

It is made available under a CC-BY-NC-ND 4.0 International license .

\section{RESULTS}

$56 \mathrm{SSc}$ patients (53 female, 3 male) with a mean age of $48.08 \pm 13.59$ years and 58 healthy volunteers (54 female, 4 male) with a mean age of $48.01 \pm 11.59$ were included in the study. The comparison of the groups in terms of age and gender was found to be similar $(p>0.05)$. In the comparison made between the SSc and control groups, smoking and accompanying comorbid diseases of the individuals were found to be similar.

The comparison of the SSc and control groups in terms of study parameters are shown in Table 1. There was no significant difference between the SSc and control groups in terms of hemoglobin, thrombocyte, neutrophil, creatinine, and alanine aminotransferase averages ( $>00.05)$. The mean C-reactive protein (CRP) was found to be significantly higher in the SSc group $(0.565 \pm 0.340)$ compared to the control group $(0.412 \pm 0.202)(\mathbf{p}<\mathbf{0 . 0 1})$. Erythrocyte sedimentation rate (ESR) mean was found to be significantly higher in the SSc group $(12.802 \pm 7.33)$ compared to the control group $(9.68 \pm 7.77)(\mathbf{p}<\mathbf{0 . 0 5})$. In comparison with the mean of Netrin-1 statistically higher levels of Netrin-1 were found in the SSc patient group (309.51 \pm 211.86$)$ compared to the control group $(125.36 \pm 83.8)(\mathbf{p}<\mathbf{0 . 0 0 1})$. Figure 1 shows the distribution of the mean of Netrin-1 between the patient and control groups.

Demographic, clinical, and laboratory data of SSc patients are shown in Table 2. The disease duration of SSc patients ranged from 1-36 years (mean 13.01 \pm 8.7$) .43(\% 76.7) \mathrm{SSc}$ patients had the diffuse disease and $13(\% 23.3)$ had limited disease subtype. Although there was Raynaud's disease in 28 patients, interstitial lung disease in 32 patients, cardiac involvement in 2 patients, and pulmonary arterial hypertension in 2 patients, there was no patient with a history of renal crisis as the involvement pattern. 5 patients had overlapping rheumatoid arthritis, Sjogren's, or myositis accompanying SSc. \%55.3 (n:31) of the patients had anti-Scl70 antibodies and \%37.5 (n:21) had anti-centromere antibodies. Antibody positivity was not found in \%7.2 (n:4) of the patients. SSc patients received different treatments according to their existing complications [hydroxychloroquine $50(\% 89.2)$, colchicine $13(\% 23.2)$, corticosteroids 
medRxiv preprint doi: https://doi.org/10.1101/2022.02.05.22270510; this version posted February 10, 2022. The copyright holder for this preprint (which was not certified by peer review) is the author/funder, who has granted medRxiv a license to display the preprint in It is made available under a CC-BY-NC-ND 4.0 International license .

7 (\%12.5), pentoxylin $10(\% 17.8), 5$-phosphodiesterase inhibitor $8(\% 14.2)$, endothelin receptor antagonist $3(\% 5.3)$, acetylsalicylic acid $42(\% 75)$, azathioprine $20(\% 35.7)$, cyclophosphamide $5(\% 8.9)]$.

Analysis of multiple variances among organ involvement patterns (Raynaud's disease, interstitial lung disease, cardiac involvement, pulmonary arterial hypertension, renal crisis) among SSc patients, no significant difference was observed between organ involvement patterns and Netrin-1 in the ANOVA post hoc Tukey test $(\mathrm{p}<0,05)$. In the analysis of multiple variances performed according to the presence of antibodies (anti-Scl70, ACA, antibody-negative) in SSc patients, no significant correlation was found between the presence of antibodies and Netrin-1 levels $(\mathrm{p}<0.05)$.

There was no significant difference in the mean of Netrin-1 between those with Raynaud's disease (325.88 \pm 208.30$)$ and those without (337.31 \pm 209.48$)$ in SSc (p>0.05). There was no significant difference in the mean of Netrin-1 between those with interstitial lung disease $(348.28 \pm 192.55)$ and those without $(309.36 \pm 227.28)(\mathrm{p}>0.05)$. Evaluation in terms of pulmonary arterial hypertension (n:2), cardiac involvement (n:2), renal crisis (n:0) was not performed because the number of patients was insufficient.

Table 3 shows the ROC analysis results for Netrin-1 in SSc. When the cut-off value of 354.24 was taken for Netrin-1 in the diagnosis of SSc, it was determined that the sensitivity of the test was $\% 32.8$ and the specificity was $\% 98.3$, giving a sensitive confidence interval (AUC [ $95 \% \mathrm{Cl}]: 0.746-0.895, \mathrm{p}<0.001)$. Figure 2 shows the ROC analysis graph of Netrin-1 levels.

Table 4 shows the correlation analysis between study parameters, patient age, and disease duration. A statistically significant positive correlation was found between ESR and patient age ( $\mathrm{r}: 0.431, \mathrm{p}<0.01)$ and disease duration $(\mathrm{r}: 0.847, \mathrm{p}<0.01)$. A negative correlation was found between MRS and patient age ( $\mathrm{r}:-0.293, \mathrm{p}<0.05)$. No correlation was observed between Netrin-1 and MRS, CRP, ESR, patient age, and disease duration ( $\mathrm{p}>0.05)$. 
medRxiv preprint doi: https://doi.org/10.1101/2022.02.05.22270510; this version posted February 10, 2022. The copyright holder for this preprint (which was not certified by peer review) is the author/funder, who has granted medRxiv a license to display the preprint in

It is made available under a CC-BY-NC-ND 4.0 International license .

\section{DISCUSSION}

SSc is a progressive disease that pathophysiologically starts with microvascular damage and then develops widespread fibrosis due to increased autoimmune response and inflammation.[18] Dysregulations in vasodilators (nitric oxide [NO], prostacyclins), cell adhesion molecules (e.g. selectins, integrins), and vasoconstrictors are thought to be responsible for the microvascular abnormalities and endothelial dysfunction seen in SSc.[19] In addition, it has been reported that decreased release of vasodilator neuropeptides (serotonin and calcitonin gene-related peptide, etc.) from sensory nerve endings and increased vasoconstrictive responses of vascular smooth muscle $\alpha 2 \mathrm{c}$ adrenoceptors to stimuli contribute to the vasculopathy seen in SSc.[20-22]

There are limited studies in the literature evaluating the relationship of Netrin-1 with SSc. Two publications are evaluating the association with Netrin-1 in bleomycin-induced lung fibrosis in mice and SSc lung cell culture in humans. Ruijuan G. and et al. showed that lung fibrosis due to bleomycin in mice is stimulated by macrophage-derived Netrin-1 concerning the adrenergic nerve.[16] In a study conducted in human SSc lung cell culture, it was shown that Netrin-1 expression increased in SSc lung cells. In this study, it was also found that bleomycininduced lung fibrosis and fibrocyte accumulation did not occur in the absence of Netrin-1 in mice.[17] However, there is no study evaluating Netrin-1 plasma levels in the SSc patient population. In this study, we investigated the relationship between SSc disease and Netrin-1 plasma levels. In the results we obtained, we found that the mean of Netrin-1 was significantly higher in SSc than in healthy controls $(\mathrm{p}<0.001)$. In our study, while Netrin-1 was not found to be associated with SSc organ involvement and skin firmness ( $p>0.05)$, we found that it has a high specificity (\%98.3) diagnostic value in SSc (AUC[95\% Cl]: 0.746-0.895, $\mathrm{p}<0.001)$.

It has been reported in the recent literature that VEGF-A, a proangiogenic factor, plays a role in the pathophysiology of SSc. However, although it has been shown that there is an increase in VEGF-A in the serum and skin tissue samples of patients with SSc, it is also known that there is angiogenin nesis deficiency in SSc.[23] In studies, it has been determined that VEGF165b antiangiogenic isoform and VEGF165 proangiogenic isoform are found due to 
medRxiv preprint doi: https://doi.org/10.1101/2022.02.05.22270510; this version posted February 10, 2022. The copyright holder for this preprint (which was not certified by peer review) is the author/funder, who has granted medRxiv a license to display the preprint in It is made available under a CC-BY-NC-ND 4.0 International license .

alternative splicing in VEGF-A pre-mRNA.[24, 25]. It has been reported that VEGF165b is stored at high levels in platelets in SSc and may cause high serum VEGF165b levels by activating the platelets by contacting the damaged SSc endothelium.[26] In a study examining the dermis of the SSc, it was reported that VEGF165b antiangiogenic isoform was overexpressed in fibroblasts, endothelial and perivascular mononuclear inflammatory cells, and the elevation in VEGF165b levels correlated with vascular loss in nail capillaroscopy.[27] In the results of the research, it has been determined that Netrin-1 increases both VEGF expression and VEGF receptor response. In animal studies in which experimental limb ischemia was created, it was shown that VEGF expression was significantly higher in subjects who received Netrin-1 treatment compared to those who did not $(\mathrm{p}<0.01) .[13,14]$ Similarly, in a study by Park et al., it was found that Netrin-1 is a strong vascular mitogen, and it increases VEGF, VEGF receptor level, and VEGF receptor responses. [15] However, although it has been reported that Netrin-1 increases VEGF in these studies, it has not been evaluated which VEGF isoforms it increases. Further research studies evaluating the association of Netrin-1 with VEGF in SSc are required. Detection of the role of VEGF165b increase due to Netrin-1 in the pathophysiology of angiogenesis failure in Ssc seems to be an interesting result.

Macrophages formed by monocyte differentiation can have two different cell phenotypes classified according to the markers on the cell surface: Classically activated (M1) and/or alternatively activated (M2) form.[28] M1 macrophages are generally accepted as effector phagocytic cells that can produce microbicidal or tumoricidal effects by secreting proinflammatory cytokines such as IL-1, IL-6, TNF-alpha. M2 polarized macrophages, which have anti-inflammatory properties, are generally involved in the synthesis of cytokines such as IL-13, IL-10, IL-4.[29] As inducers of tissue fibrosis in SSc, M2 macrophages act at the apex of the profibrotic late immune response or during wound healing of tissues. It has been reported that M2 macrophages increase extracellular matrix (ECM) protein synthesis together with profibrotic cytokine synthesis, partially suppress M1-induced inflammation, and also strengthen the anti-inflammatory response by inducing Th2 effector cell activity.[29] Similarly, in another 
medRxiv preprint doi: https://doi.org/10.1101/2022.02.05.22270510; this version posted February 10, 2022. The copyright holder for this preprint (which was not certified by peer review) is the author/funder, who has granted medRxiv a license to display the preprint in

It is made available under a CC-BY-NC-ND 4.0 International license .

study on gastric malignancy, M2 macrophages were found to cause ECM increase.[30]

Interestingly, the results obtained from studies show that M1 macrophage marker expression is suppressed due to Netrin-1, while M2 macrophage marker expression is increased.[31-33].

These results suggest that Netrin-1 may be a possible candidate mediating the known effects of M2 macrophages on ECM increase in SSc.

\section{CONCLUSION}

As a result of the study, we determined that the increase in Netrin-1 plasma levels is closely related to SSc disease. Considering the known roles of VEGF and M2 macrophages in the development of SSc and their close relationship with Netrin-1, further studies in this area seem to create a fertile field in understanding the complex pathophysiology of SSc and offering new therapeutic options. The most important limitation of our study is that it is a cross-sectional study and only a small number of patients were included in the study.

\section{RESOURCES}

1. Flower VA, Barratt SL, Ward S, et al. The Role of Vascular Endothelial Growth Factor in Systemic Sclerosis. Current rheumatology reviews, 2019;15.2: 99-109.

2. Bradford D, Faull RL, Curtis MA, et al. Characterization of the netrin/RGMa receptor neogenin in neurogenic regions of the mouse and human adult forebrain. J Comp Neurol 2010;518:3237-3253.

3. Medeiros A, Wilder T, Ramkhelawon B, et al. Netrin-1 and its receptor Unc5b are novel targets for the treatment of inflammatory arthritis. The FASEB Journal, 2016;30.11:38353844.

4. Mediero A, Ramkhelawon B, Perez-Aso M, et al. Netrin-1 is a critical autocrine/paracrine factor for osteoclast differentiation. Journal of Bone and Mineral Research, 2015;30.5:837854.

5. Van Gils JM, Derby MC, Fernandes LR, et al. The neuroimmune guidance cue netrin-1 
medRxiv preprint doi: https://doi.org/10.1101/2022.02.05.22270510; this version posted February 10, 2022. The copyright holder for this preprint (which was not certified by peer review) is the author/funder, who has granted medRxiv a license to display the preprint in It is made available under a CC-BY-NC-ND 4.0 International license.

promotes atherosclerosis by inhibiting the emigration of macrophages from plaques. Nat. Immunol. 2012;13:136-143.

6. Ramkhelawon B, Hennessy EJ, Menager M, et al. Netrin-1 promotes adipose tissue macrophage retention and insulin resistance in obesity. Nat. Med. 2014:20;377-384.

7. Ramkhelawon B, Yang Y, van Gils JM, et al. Hypoxia induces netrin-1 and Unc 5b in atherosclerotic plaques: a mechanism for macrophage retention and survival. Arterioscler Thromb Vasc Biol. 2013;33.6:1180-1188.

8. Nguyen A, Cai H. Netrin-1 induces angiogenesis via a DCC-dependent ERK1/2-eNOS feed-forward mechanism. Proc Natl Acad Sci U S A 2006:103:6530-6535.

9. Wu TW, Li WW, Li H. Netrin-1 attenuates ischemic stroke-induced apoptosis. Neuroscience 2008;156:475-482.

10. Mohamed R, Jayakumar C, Ranganathan PV, et al. Ramesh G. Kidney proximal tubular epithelial-specific overexpression of netrin-1 suppresses inflammation and albuminuria through suppression of COX-2-mediated PGE2 production in streptozotocin-induced diabetic mice. Am J Pathol 2012;181:1991-2002.

11. Zhang J, Cai H. Netrin-1 prevents ischemia/reperfusion-induced myocardial infarction via a DCC/ ERK1/2/eNOS s1177/NO/DCC feed-forward mechanism. J Mol Cell Cardiol 2010;48:1060-1070.

12. Toque HA, Fernandez-Flores A, Mohamed R, et al. Netrin-1 is a novel regulator of vascular endothelial function in diabetes. PLoS One, 2017;12.10; 0186734.

13. Chen T, Chen D, Li F, et al. Netrin-1 with stem cells promote angiogenesis in limb ischemic rats. journal of surgical research, 2014; 192.2: 664-669.

14. Ke X, Liu C, Wang Y, et al. Mao X., et al. Netrin-1 promotes mesenchymal stem cell revascularization of limb ischemia. Diabetes and Vascular Disease Research, 2016;13.2:145-156.

15. Park KW, Crouse D, Lee M, et al. The axonal attractant Netrin-1 is an angiogenic factor. Proceedings of the National Academy of Sciences, 2004;10.46:16210-16215.

16. Gao R, Peng X, Perry C, et al. Macrophage-derived netrin-1 drives adrenergic nerve- 
medRxiv preprint doi: https://doi.org/10.1101/2022.02.05.22270510; this version posted February 10, 2022. The copyright holder for this preprint (which was not certified by peer review) is the author/funder, who has granted medRxiv a license to display the preprint in It is made available under a CC-BY-NC-ND 4.0 International license .

associated lung fibrosis. The Journal of clinical investigation, 2021;131.1

17. Sun H, Zhu Y, Pan H, et al. Netrin-1 Regulates Fibrocyte Accumulation in the Decellularized Fibrotic Sclerodermatous Lung Microenvironment and bleomycin-Induced Pulmonary Fibrosis. Arthritis \& Rheumatology, 2016:68.5:1251-1261.

18. Cutolo M, Sulli A, Smith V. Assessing microvascular changes in systemic sclerosis diagnosis and management. Nat Rev Rheumatol. 2010;6:578-587.

19. Mostmans Y, Cutolo M, Giddelo C, et al. The role of endothelial cells in the vasculopathy of systemic sclerosis: a systematic review. Autoimmun Rev. 2017;16:774-786.

20. Vega AV, Avila G. CGRP, a vasodilator neuropeptide that stimulates neuromuscular transmission and EC coupling. Curr Vasc Pharmacol. 2010;8:394-403.

21. Iwamoto N, Distler O. Molecular targets for therapy in systemic sclerosis. Fibrogenesis Tissue Repair. 2012;5.1:19.

22. Wigley FM, Flavahan NA. Raynaud's Phenomenon. N Engl J Med. 2016;375:556-565.

23. Distler O, Distler JH, Scheid A, et al. Uncontrolled expression of vascular endothelial growth factor and its receptors leads to insufficient skin angiogenesis in patients with systemic sclerosis. Circ Res. 2004;95:109-116.

24. Manetti M, Guiducci S, Romano E, et al. Overexpression of VEGF165b, an inhibitory splice variant of vascular endothelial growth factor, leads to insufficient angiogenesis in patients with systemic sclerosis. Circ Res. 2011;109:14-26.

25. Manetti M, Guiducci S, Romano E, et al. Increased plasma levels of the VEGF165b splice variant are associated with the severity of nail fold capillary loss in systemic sclerosis. Ann Rheum Dis. 2013;72:1425-1427.

26. Hirigoyen D, Burgos PI, Mezzano V, et al. Inhibition of angiogenesis by platelets in systemic sclerosis patients. Arthritis Res Ther. 2015; 19.17: 332.

27. Cutolo M, Soldano S, Smith V. Pathophysiology of systemic sclerosis: current understanding and new insights. Expert review of clinical immunology, 2019:15.7:753-764.

28. Manetti M. Deciphering the alternatively activated (M2) phenotype of macrophages in scleroderma. Exp Dermatol. 2015;24:576-578. 
medRxiv preprint doi: https://doi.org/10.1101/2022.02.05.22270510; this version posted February 10, 2022. The copyright holder for this preprint (which was not certified by peer review) is the author/funder, who has granted medRxiv a license to display the preprint in It is made available under a CC-BY-NC-ND 4.0 International license .

29. Funes SC, Rios M, Escobar-Vera J, et al. M. Implications of macrophage polarization in autoimmunity. Immunology. 2018;154:186-195.

30. Li W, Zhang X, Wu F, et al. Gastric cancer-derived mesenchymal stromal cells trigger M2 macrophage polarization that promotes metastasis and EMT in gastric cancer. Cell Death Dis. 2019;10.12:918-6

31. Ranganathan P, Mohamed R, Jayakumar C, et al. Guidance cue netrin-1 and the regulation of inflammation in acute and chronic kidney disease. Mediators of inflammation, 2014.

32. Zhang Y, Chen P, Di G, et al. Netrin-1 promotes diabetic corneal wound healing through molecular mechanisms mediated via the adenosine 2B receptor. Scientific reports, 2018;8.1:1-12.

33. Ranganathan PV, Jayakumar C, Ramesh G. Netrin-1-treated macrophages protect the kidney against ischemia-reperfusion injury and suppress inflammation by inducing M2 polarization. American Journal of Physiology-Renal Physiology, 2013;304.7:948-957.

\section{Acknowledgments}

We would like to thank the Turkish Rheumatology Association for its educational support regardless of benefits.

\section{Ethics approval}

The ethics committee approval of the research protocol was made by the Ankara City Hospital Ethics Committee. Informed consent was obtained from the patients to participate in the study.

\section{Conflicts of interest}

None declared. 
medRxiv preprint doi: https://doi.org/10.1101/2022.02.05.22270510; this version posted February 10, 2022. The copyright holder for this preprint (which was not certified by peer review) is the author/funder, who has granted medRxiv a license to display the preprint in

It is made available under a CC-BY-NC-ND 4.0 International license .

Table 1. Comparison of Study Parameters SSc and Control Groups.

\begin{tabular}{|llll|} 
Parameter & SSc & Control & P-Value \\
\hline Hemoglobin, mean $\pm \mathrm{SD}\left[\mathrm{x} 10^{\wedge} 9 / \mathrm{L}\right]$ & $13.11 \pm 1.19$ & $13.31 \pm 1.36$ & $>0.05$ \\
\hline Trombosit, mean $\pm \mathrm{SD}\left[\mathrm{x} 10^{\wedge} 9 / \mathrm{L}\right]$ & $280.60 \pm 84.07$ & $272.71 \pm 64.20$ & $>0.05$ \\
\hline WBC, mean $\pm \mathrm{SD}\left[\mathrm{x} 10^{\wedge} / \mathrm{L}\right]$ & $7.43 \pm 1.88$ & $6.89 \pm 1.79$ & $>0.05$ \\
\hline Nötrofil, mean $\pm \mathrm{SD}\left[\mathrm{x} 10^{\wedge} 9 / \mathrm{L}\right]$ & $5.84 \pm 2.87$ & $4.39 \pm 1.81$ & $>0.05$ \\
\hline Creatinine, mean $\pm \mathrm{SD}[\mathrm{mg} / \mathrm{dl}]$ & $0.66 \pm 0.14$ & $0.70 \pm 0.11$ & $>0.05$ \\
\hline ALT, mean $\pm \mathrm{SD}[\mathrm{mg} / \mathrm{dl}]$ & $19.86 \pm 16.61$ & $23.87 \pm 9.76$ & $>0.05$ \\
\hline CRP mean $\pm \mathrm{SD}[\mathrm{mg} / \mathrm{dl}]$ & $0.565 \pm 0.340$ & $0,412 \pm 0,202$ & $<\mathbf{0 . 0 1}$ \\
\hline ESR mean $\pm \mathrm{SD}[\mathrm{mm} / \mathrm{h}]$ & $12.802 \pm 7.33$ & $9.68 \pm 7.77$ & $<\mathbf{0 . 0 5}$ \\
\hline Netrin-1 mean $\pm \mathrm{SD}[\mathrm{pg} / \mathrm{mL}]$ & $309.51 \pm 211.86$ & $125.36 \pm 83.81$ & $<\mathbf{0 . 0 0 1}$
\end{tabular}

All values were expressed as mean $\pm S D$. All values were calculated using İndependent SampTtestest for normal distribution. CRP: C-reactive protein, ESR: Erythrocyte Sedimentation Rate, WBC: White blood cells, ALT: Alanine aminotransferase

Table 2. Demographic, Clinical, and Laboratory Data of SSc patients

\begin{tabular}{|l|l|}
\hline Parameters & Value \\
\hline Disease duration, mean \pm SD (range) [years] & $13.01 \pm 8.7(1-36)$ \\
\hline Disease subtype diffuse/limited, $\mathrm{n}(\%)$ & $43 / 13(76.7 / 23.3)$ \\
\hline Raynaud's disease, $\mathrm{n}(\%)$ & $28(50)$ \\
\hline İnterstitial lung disease, $\mathrm{n}(\%)$ & $32(57.1)$ \\
\hline Cardiac involvement, $\mathrm{n}(\%)$ & $2(3.5)$ \\
\hline Pulmonary arterial hypertension, $\mathrm{n}(\%)$ & $2(3.5)$ \\
\hline Renal crisis, $\mathrm{n}(\%)$ & $0(0)$ \\
\hline Concomitant disease (RA, Sjogren's, myositis), $\mathrm{n}(\%)$ & $5(8.9)$ \\
\hline Anti-Scl70 antibody positivity, $\mathrm{n}(\%)$ & $31(55.3)$ \\
\hline ACA positivity & $21(37.5)$ \\
\hline Antibody negative & $4(7.2)$ \\
\hline Modified Rodnan Score, mean $\pm \mathrm{SD}($ range) & $6.58 \pm 5.20(2-23)$ \\
\hline Medical therapy, $\mathbf{n}(\%)$ & \\
\hline Hydroxychloroquine, $\mathrm{n}(\%)$ & $50(89.2)$ \\
\hline Colchicine, $\mathrm{n}(\%)$ & $13(23.2)$ \\
\hline Corticosteroids, $\mathrm{n}(\%)$ & $7(12.5)$ \\
\hline Calcium channel blocker, $\mathrm{n}(\%)$ & $38(67.8)$ \\
\hline Pentoxylin, $\mathrm{n}(\%)$ & $10(17.8)$ \\
\hline 5-phosphodiesterase inhibitor, $\mathrm{n}(\%)$ & $8(14.2)$ \\
\hline Endothelin receptor antagonist, $\mathrm{n}(\%)$ & $3(5.3)$ \\
\hline Acetylsalicylic acid, $\mathrm{n}(\%)$ & $42(75)$ \\
\hline Azathioprine, $\mathrm{n}(\%)$ & $20(35.7)$ \\
\hline Cyclophosphamide, $\mathrm{n}(\%)$ & $5(8.9)$ \\
\hline
\end{tabular}

SSc: Systemic Sclerosis, ACA: Anti-centromere Antibody, RA: Rheumatoid Arthritis 
medRxiv preprint doi: $h$ ttps://doi.org/10.1101/2022.02.05.22270510; this version posted February 10, 2022. The copyright holder for this preprint (which was not certified by peer review) is the author/funder, who has granted medRxiv a license to display the preprint in It is made available under a CC-BY-NC-ND 4.0 International license

Table 3. Specificity, Sensitivity, and the Cut-off Levels of Netrin-1 in SSc

\begin{tabular}{|lllllll|}
\hline & Cut-off & AUC $(\% 95 \mathrm{Cl})$ & $\begin{array}{l}\text { Sensitivity } \\
(\%)\end{array}$ & $\begin{array}{c}\text { Specificity } \\
(\%)\end{array}$ & LR & p-value \\
\hline Netrin-1 & 354.24 & $0.821(0.746-0.895)$ & 32.8 & 98.3 & 19 & $<\mathbf{0 . 0 0 1}$ \\
\hline
\end{tabular}

AUC: Area under the ROC Curve, LR: Likelihood ratio, SSc: Systemic Sclerosis

Table 4. Correlation Between Study Parameters

\begin{tabular}{lllllll|} 
Parameter & Netrin-1 & CRP & ESR & MRS & \multicolumn{2}{l}{ Patient age Disease Duration } \\
Netrin-1 & - & 0.093 & 0.097 & 0.089 & 0.075 & 0.030 \\
\hline CRP & 0.093 & - & 0.124 & 0.073 & 0.013 & 0.145 \\
\hline ESR & 0.097 & 0.124 & - & -0.040 & $0.431^{* *}$ & $\mathbf{0 . 8 4 7}^{* *}$ \\
MRS & -0.069 & 0.073 & -0.040 & - & $\mathbf{- 0 . 2 9 3}^{*}$ & -0.55 \\
\hline Patient age & 0.075 & 0.013 & $\mathbf{0 . 4 3 1}^{* *}$ & $\mathbf{- 0 . 2 9 3}^{*}$ & - & 0.535 \\
\hline Disease Duration & 0.030 & 0.145 & $\mathbf{0 . 8 4 7}^{* *}$ & -0.55 & 0.535 & - \\
\hline
\end{tabular}

All values were calculated using Pearson correlation analysis. * $p<0.05, * * p<0.01$. CRP: Creactive protein, ESR: Erythrocyte Sedimentation Rate, MRS: Modified Rodnan Score

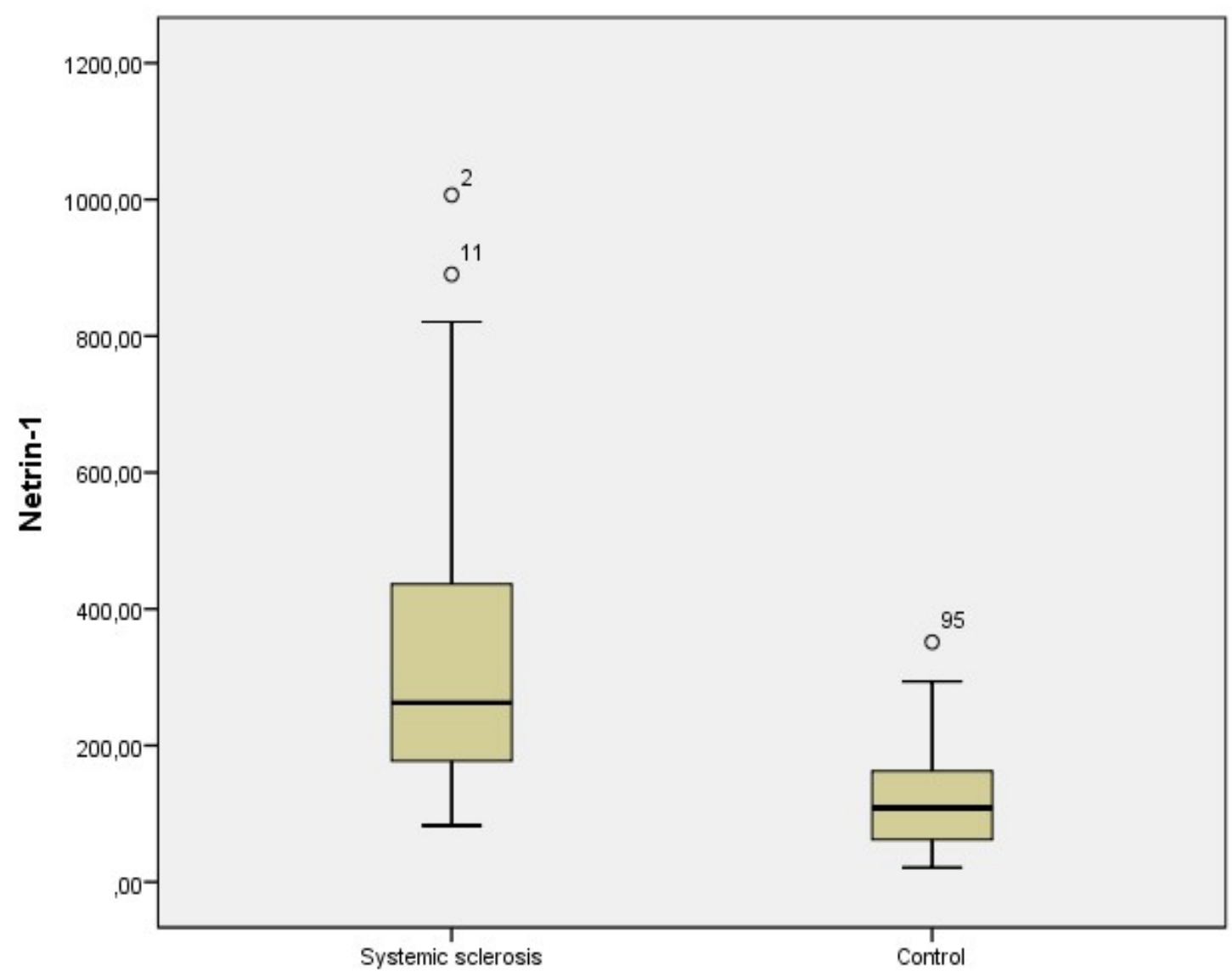

Fig. 1. Netrin-1 mean between group 
medRxiv preprint doi: https://doi.org/10.1101/2022.02.05.22270510; this version posted February 10, 2022. The copyright holder for this preprint (which was not certified by peer review) is the author/funder, who has granted medRxiv a license to display the preprint in

It is made available under a CC-BY-NC-ND 4.0 International license .

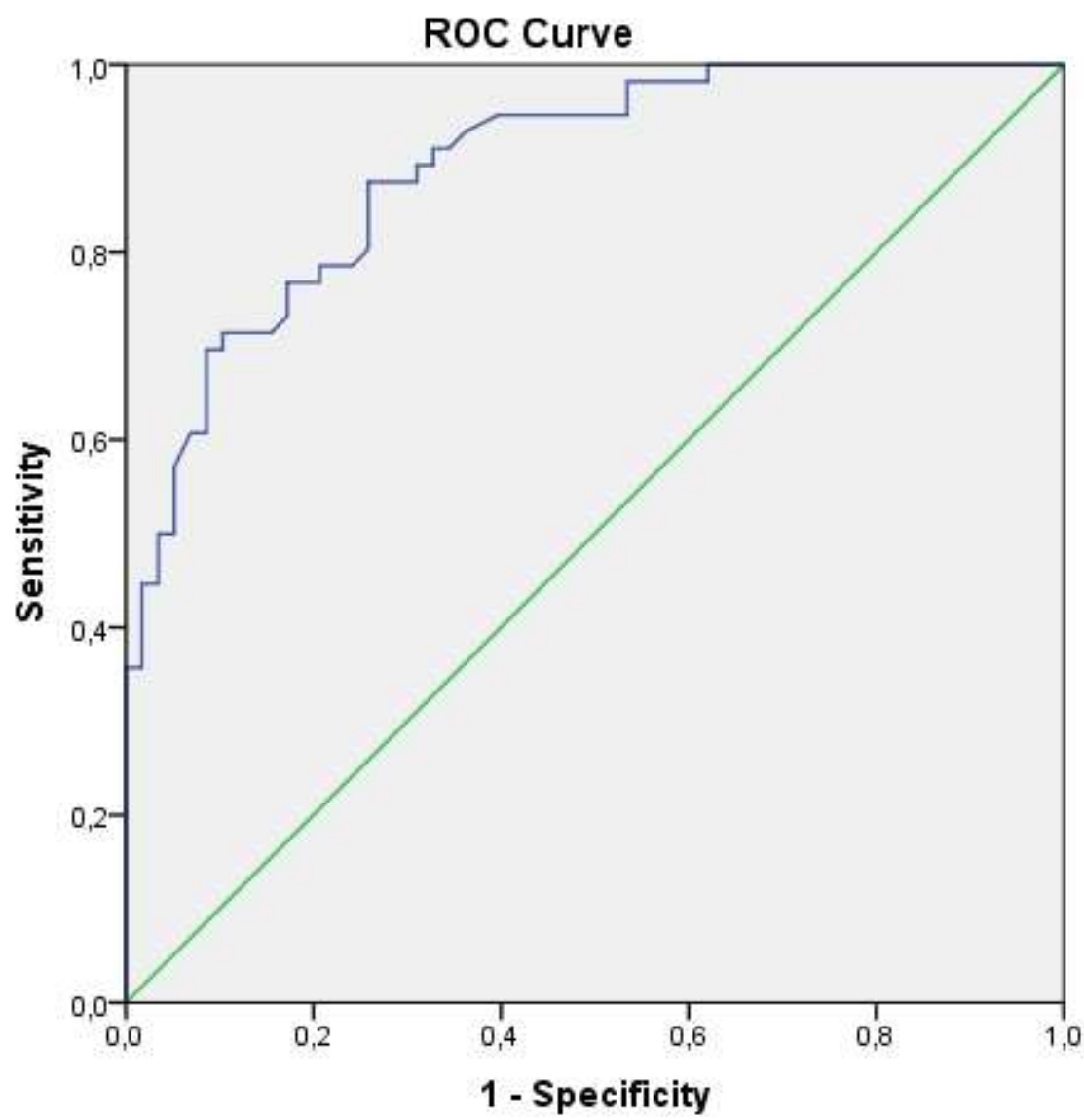

Fig.2. ROC curves of levels of Netrin-1 in systemic sclerosis 